\title{
Increase Creativity And Imagination Children Through Learning Science, Technologic, Engineering, Art And Mathematic With Loose Parts Media
}

\author{
Nipriansyah $^{1, *}$, Rambat Nur Sasongko ${ }^{2}$, Muhammad Kristiawan ${ }^{2}$, Edy Susanto $^{3}$, Putri \\ Fatmawati Arinal Hasanah ${ }^{4}$ \\ ${ }^{1}$ SKB Distric Kaur Bengkulu, Indonesia \\ ${ }^{2}$ Bengkulu of University, Indonesia \\ ${ }^{3}$ Dehasen Bengkulu University, Indonesia \\ ${ }^{4}$ Universitas Negeri Jakarta, Indonesia \\ *danknipriansyah@gmail.com
}

\begin{abstract}
The STEAM method is applied to early childhood to provide broader thinking power in problem solving. Penelitian aims to describe the learning STEAM (Science, Technological, Engineering, Art and Mathematic) with media loose parts that can enhance the creativity and imagination of children. The research method used is descriptive qualitative using observation, interviews and documentation. In data analysis techniques, researchers used qualitative analysis techniques using data reduction, data presentation, and drawing conclusions. The research was conducted in 4 meetings in group B with 12 children. The results showed that STEAM learning with losse parts media could increase children's creativity and imagination. This can be seen from the observation that was made 4 times, all children experienced good development when learning with losse parts media.learning STEAM with losse parts can be applied to earlyplay groups childhood education, both inand kindergarten. This research not only improvescreativity children'sbut also increases children's imagination, the loose parts media used are also unique and natural.
\end{abstract}

Keywords: STEAM learning; loose parts; children's creativity and imagination

\section{Meningkatkan Kreativitas Dan Imajinasi Anak Melalui Pembelajaran Science, Technologic, Engineering, Art And Mathematic (STEAM) Dengan Media Loose Parts}

\begin{abstract}
Abstrak
Metode STEAM diterapkan pada anak usia dini untuk memberikan daya pikir yang lebih luas dalam pemecahan masalah. Penelitian ini bertujuan mendeskripsikan pembelajaran STEAM (Science, Technological, Engineering, Art and Mathematic) dengan media loose parts yang dapat meningkatkan kreativitas dan imajinasi anak. Metode penelitian yang digunakan adalah deskriptif kualitatif dengan menggunakan observasi, wawancara dan dokumentasi. Dalam teknik analisis data, peneliti menggunakan teknik analisis kualitatif dengan menggunakan reduksi data, penyajian data, dan penarikan kesimpulan. Penelitian dilakukan sebanyak 4 kali pertemuan pada kelompok B dengan 12 anak. Hasil penelitian menunjukkan bahwa pembelajaran STEAM dengan media losse parts dapat meningkatkan kreativitas dan imajinasi anak, hal ini terlihat dari observasi yang dilakukan sebanyak 4 kali, semua anak mengalami perkembangan yang baik saat belajar dengan media losse parts. Pembelajaran STEAM dengan losse parts dapat diaplikasikan pada PAUD baik dikelompok bermain maupun Taman kanakkakak. Penelitian ini tidak hanya meningkatkan kreativitas anak tetapi juga meningkatkan imajinasi anak, media loose parts yang digunakan juga unik dan natural.
\end{abstract}

Kata Kunci: pembelajaran STEAM; loose parts; kreativitas dan imajinasi anak-anak 


\section{INTRODUCTION}

The existence of early childhood education as well as non-formal and informal education is very urgent in the effort to achieve the goals of national education. Paud is a preprimary education level that fosters early childhood from birth to 6 years of age. Which is given educational stimulation to help the growth and development of children both physically and spiritually in the face of further education. Early childhood education directs paud organizers to emphasize the growth and development aspects of children (religion and moral, physical motor, cognitive, language, social-emotional, and art) in accordance with the uniqueness according to the development stages that early childhood goes through as stated in Permendikbud 1372014 on the National Standard for Early Childhood Education.

In the era of the 21st century, we have entered the era of the Industrial Revolution 4.0 and an era of disruption that increasingly demands that we be more creative and innovative. Early childhood education is one of the education units that must be ready to make changes and respond to the challenges of the times. Early childhood is a golden period or golden age which is very decisive and very influential on the development of the next child, so that at this golden age the child must get the right stimulation or stimulation (Wiyani 2019).

Starting from an early age, children must be given skills both hard skills and soft skills so that children are able to adapt to changes in their environment. Skills that need to be taught to children are critical thinking skills, creative thinking (creativity), cooperation, and communication. Besides of course, children learn about knowledge (physical knowledge, mathematical logic, and social), these skills must be integrated in the learning process $n$ (Wahyuningsih, Pudyaningtyas, and Nurjanah 2020)

In preparing the golden generation with a scientific mindset and high reasoning abilities, children can be trained in Science, Technologic, Engineering, Art and Mathematic learning models. Learning by utilizing science, technology, engineering, art and mathematics in an integrated manner is centered on students that have been developed in various countries from pre-school to high school levels. In improving higher-order thinking skills and motor skills in early childhood, the approach of Science, Technological, Engineering, Art and Mathematic can be emphasized in the learning process through hands-on activities (Sugawara and Nikaido 2014) 
Learning with Science, Technological, Engineering, Art and Mathematic content is relevant to the content of the 2013 PAUD curriculum, namely the scientific approach inviting children to observe, ask, collect information, reason, and communicate. At the same time, learning Science, Technologic, Engineering, Art and Mathematic is important to help teachers combine various disciplines and introduce children's learning experiences that give children the freedom to explore, ask, research, find and practice innovative skills (Nurjanah 2020).

As research conducted by (Becker \& Park) that the STEAM learning approach has a positive effect on students, is able to train students cognitive, skill, and affective, apart from being taught in theory it is also taught practice making students have direct experience in the process learning (Wahyuni, Reswita, and Afidah 2020). Media loose parts are one of the media used in the learning of Science, Technologic, Engineering, Art and Mathematic (Prameswari and Lestariningrum 2020). Loose parts are open materials, materials that do not combine with other materials that can be combined, carried, assembled, used alone or combined with other materials (Wahyuningsih, Pudyaningtyas, and Nurjanah 2020). Loose parts materials are easy to find in everyday life and even loose parts are often used and utilized. Loose parts in nature around us such as coral, river sand, sea sand, clay, leaves and twigs are very easy to obtain, loose parts from used materials such as plastic, metal, glass are also very easy to get, even it doesn't cost money to get it. the loose parts material. Loose parts materials can support children's development and help children to connect themselves with the child's environment (Prameswari and Anik Lestariningrum 2020)

Loose parts consist of 7 types: 1) Natural materials, which are natural materials such as: cassava leaves, corn kernels, bricks (Ubaidillah 2018), 2) Plastic materials, materials made of plastic such as: shirt buttons, used bottles, plastic straws, bottle caps, pieces of paralon, plastic buckets and pans (Budiarti, Susilowati, and Farida 2018), 3) Metal, is a material made of metal, such as: tablespoons, used paint cans, zinc, kitchen utensils, screwdrivers, hammers, keys, knives, pans (Chairunnisah, Sulaiman, and Fitrani 2019). 4) Wood and bamboo, are materials from wood and bamboo that are no longer used: pen holders, wooden blocks, puzzles made of flute wood and others. 5) Yarn and cloth, are materials made from fiber materials such as: handkerchiefs, cotton, patchwork, ropes, ribbons, rubber and others. 6) Glass and ceramics, are materials from glass and ceramics, such as: glass, glass bottles, mirrors, beads, marbles, ceramics, and others (Palupi 2019). 7) 
Former packaging, is used packaging materials such as: cardboard noodles, tissue rolls, cake wrappers, egg containers, bread containers and others (Agustina, Nasirun, and Delrefi 2018).

Early Childhood Education educators and parents have assumed that good toy materials to stimulate children's development are materials obtained from buying or manufactured materials, even though there are so many materials around us that can be used as learning materials. while playing early childhood in accordance with the creativity and imagination of children. Every object played by children can be used according to imagination, creativity and innovation to stimulate children to think about science with the materials that have been provided (Prameswari and Anik Lestariningrum 2020)

In early childhood cognitive development, visualization is still needed in transferring knowledge, this learning process requires interesting media or tools to stimulate children's motor development. Media loose parts are one step that can be developed as an educational game with Science, Technological, Engineering, Art and Mathematic (Puspita 2019). Playing children's activities using play materials or assistive media can make early childhood more creative and free to imagine according to children's wishes (Anita Damayanti, Sriyanti Rahmatunnisa, and Lia Rahmawati 2020)

It is important to develop one's creativity from early childhood because creativity becomes the foundation for productive thinking and has the opportunity to discover new things. Creativity is a person's mentality that generates effective new ideas, processes, methods or products that are imaginative, aesthetic. Flexible. Integration, succession, discontinuity, and differentiation that are useful in solving a problem (Imamah and Muqowim 2020) James J. Gallagher and Yeni Racmawaty said that creativity is a mental process in an individual that is carried out in the form of a new idea or product, or by combining the two and in the end it will stick to the individual (Maryati 2018).

The ability of creativity is involved in the process of understanding concepts in mathematics. For this reason, teachers need to build a pleasant learning atmosphere. as a learning process that introduces students to mathematical logic that is easy to learn and remember, fun means students learn without coercion, and fun as a satisfaction in the learning process because of the use of props and games(Pratiwi et al. 2021). creativity is a new product that is effective and imaginative and useful in various fields for solving a problem. The value of creativity is not only seen from whether a work is neat or not, but rather how the work is successfully created and what is implied in the work(Anggia and Nopriansyah 2018). 
It can be concluded that children's creativity is a mental process in giving birth to new ideas or products that can combine the two effectively, imaginatively and aesthetically so that it is inherent in someone where this must be stimulated by building a pleasant learning atmosphere. as a learning process that introduces students through STEAM which is easy to learn, remember and fun means that students learn without coercion as a satisfaction in the learning process because of the use of props and games with loose part media.

Loose parts are an opportunity for children to express their creativity through the use of materials that can be manipulated, modified and made through self-guided play (Gull et al. 2019). At an early age children play, create and imagine, develop children's imagination is an effort to stimulate, grow and increase the potential for intelligence as well as creativity in their infancy. develops along with the development of the child's imagination the ability to speak and language. (Rofi'ah, Setyowati, and Idhayanti 2018)

Imagination is a cognitive behavior that occurs in the mind in the form of recognition of the environment without going through sensing and observation. Surya explains that the characteristics of imagination are (Surya, Gunadi 2017): (a) Subjective. Imagination is subjective, meaning that it is only experienced by the individual in question depending on individual conditions; (b) Realized. The imagination that a person is experiencing takes place in the conscious mind, which means being aware of all the processes and activities of his imagination; (c) In freedom. The process of imagination takes place in a free state without the binding of certain rules that usually occur in the real world; (d) Imaginary. This means that it is imaginary or fantasy, which is something that exists in the natural world and does not exist in the real world; (e) Pseudo observation. Cognition in sensing and / or observation occurs because there are observational activities of the environment with all forms of stimuli received by the sense organs or receptors; (f) Based on assumptions on something that does not exist. The assumptions used in building the imagination are usually based on things that do not actually exist in the real world; (g) Spontaneity. Given the freedom and ability of human reasoning power, imagination occurs spontaneously which is then expressed in various forms by Janice Beaty as followed.

Based on the above opinion, imagination for early childhood is the ability to respond or carry out the fantasies they make which is heavily influenced by the environment they are experiencing. There are several things that can be done to develop children's imagination, according to Musbikin, to provide learning according to children's abilities, provide a little 
imagination, jokes, and humor when teaching children with something good, do not give orders or restrictions with the word "Don't!" increasingly doing the opposite is prohibited. Give a dramatic scene when forbidding it, don't disturb children if they are engrossed in their world, give praise if the child has done something extraordinary, be a place to pay attention to the child when the child tells about his imagination and hone the imagination with fairy tales or interesting stories for children in learning (Gunadi 2017).

Previous research only emphasized the learning of Science, Technologic, Engineering, Art and Mathematic with loose parts in improving the creativity of early childhood (Nurjanah 2020), the effect of Science, Technologic, Engineering, Art and Mathematic methods on children's creativit (Wahyuningsih et al. 2019), Science, Technologic, Engineering, Art and Mathematic learning strategies by playing loose parts to achieve 4 C skills (Prameswari and Anik Lestariningrum 2020). So it is important to do research on how to increase children's creativity and imagination through STEAM (Science, Technological, Engineering, Art and Mathematic) learning with loose parts media.

Based on the results of direct interviews with several Early Childhood Education educators in Kaur Regency, there are still a lot of Early Childhood Education educators who do not understand Science, Technological, Engineering, Art and Mathematic learning, educators also do not know what media are used for learning Science, Technologic, Engineering, Art And Mathematic. Educators also do not know the benefits of learning Science, Technological, Engineering, Art and Mathematic with loose parts media in early childhood learning. So far, most educators have used worksheets as student learning media, while the learning media used by educators in children's learning activities while playing are using manufactured materials. This results in children's creativity, collaboration, communication, critical thinking underdeveloped, even though in the era of this 4.0 revolution, from an early age children must be given stimulation that makes children think critically, be able to communicate well, be able to work together and be creative. Due to the problem, the target of this research is early childhood aged 4-5 years in the Rembulan Early Childhood Education Unit, Padang Guci Subdistrict Downstream, Kaur Regency. This research will observe STEAM (Science, Technological, Engineering, Art and Mathematic) learning with loose parts media that can increase children's creativity and imagination. 


\section{RESEARCH METHODS}

The research method used in this research is to use descriptive qualitative research methods. Through this approach, it is hoped that researchers can produce descriptive data in order to reveal the causes and processes of occurrence in the field. A qualitative approach is an approach by looking at the object of study as a system, meaning that the object of study is seen as a unit consisting of interrelated elements and describes the existing phenomena.. (Anggito and Setiawan 2018)

The research method used in this study is a qualitative method of descriptive theory with qualitative data analysis, the research is a naturalistic research which is carried out in natural conditions of natural setting (Rijali 2019). In general, data collection techniques in qualitative data analysis consist of four types, namely observation, interviews, documentation, and combination / triangulation ". Triangulation is checking data from various sources in various ways, and at various times (Yayuk and Sugiyono 2019)

The main instrument or tool for data collection in qualitative research is humans or researchers themselves by observing, asking, listening, requesting and retrieving research data, so that researchers get valid data and not just any interviewee ( (Anufia and Alhamid 2019) .The instrument used in this study was in the form of an unstructured interview instrument and was free to ask what was needed by the researcher. The instruments used in the observation are in the form of observation guidelines, picture recordings, and sound recordings, the instrument used in the form of documentation is a check-list that contains a list of variables to be collected.

The implementation of this research was in the first semester of the 2020/2021 school year in the Moon Early Childhood Education unit. The implementation time was carried out 5 meetings which refer to the educational calendar in the Moon Early Childhood Education unit. Data collection was carried out through observation to students and educators and documentation when learning Science, Technological, Engineering, Art and Mathematic with Loose Parts media itself. In this descriptive method and qualitative data analysis, the researcher will discuss whether "Learning Science, Technological, Engineering, Art and Mathematic with Loose Parts media can increase the creativity and imagination of Group A children (4-5 years) in the Moon Early Childhood Education unit? " The subjects of this study were 12 children, 7 boys and 5 girls group A in the Moon Early 
Childhood Education Unit. The object used for research is the children's artistic abilities and language skills.

The data analysis used is qualitative data analysis in the form of words. Then the results of the observations were poured into the descriptive method. Then the researcher began to analyze qualitative data through interviews with the objects observed, one of which was, "How did you feel when studying with Loose Parts media?"

\section{RESULTS AND DISCUSSION}

\section{A. Result}

The design of the Science, Technologic, Engineering, Art and Mathematic learning media for group A 4-5 years in the Rembulan PAUD unit in terms of planning the Science, Technologic, Engineering, Art and Mathematic method can increase the creativity and imagination of children aged 4-5 years. The results of the study can be seen from the child's ability to optimize the use of available loose parts so that children are interested in playing with the materials that have been provided. This method puts forward science, technology, eingeneering, art and mathematic. Learning center model is used as a strategy in learning Science, Technologic, Engineering, Art and Mathematic.

The initial step is to make pre-research preparations, by finding and collecting data on children aged 4-5 years who will be studied through direct observation of the results of the learning process carried out by educators on 14 children by observing the children's work given by educators to each child by learning which only uses pencil learning media, drawing books, watercolors, and scissors. The results of observations by researchers during the initial activity, the overall presentation of creativity and imagination were $31 \%$. The low percentage of children's creativity and imagination level is due to the learning given by educators not yet based on STEAM with loose parts media. By learning STEAM with loose parts media, it is hoped that it can increase children's creativity and imagination.

\section{Activity I}

In activity I, it was held for 2 days with the aim of seeing the development of creativity and imagination of students. At this stage the educator prepares RPPH for 2 days with activities that can increase the creativity and imagination of the Rembulan PAUD students, for the first activity the educators start the activities from opening, core and 
closing, this activity is carried out by making a cow shed with loose part materials from materials wood and bamboo that have been provided by the educator. And on the second day, the main activity was to arrange houses with makeshift loose parts around the school.

In this activity there are several shortcomings, namely: a) less attractive and too watchful because the media used is only a toy tool from a manufacturer that is already in school, b) the teacher has determined the play activities that the child should do, c) the number of playing tools is just too few. In the implementation of STEAM learning with loose parts media, the creativity and imagination of students began to increase.

\section{Second activity}

For this second activity, learning activities were carried out for 2 days which aimed to improve children's creativity and imagination. In this second activity, the educators prepared RPPH for a span of 2 days with a variety of activities that could increase the creativity and imagination of PAUD Rembulan Kaur children. At the first and second meetings, the opening, core and closing activities began. In this second activity, educators prepare various loose parts both from natural materials and from materials that are around the environment, educators provide books and pictures such as pictures of views of beaches, gardens and houses and educators arrange loose parts neatly and attractively. In this second activity, children are given the freedom to create and imagine according to their wishes.

Research data from research activities are described in the table below:

Table 3. Comparative Analysis of Results Data before and after the activity

\begin{tabular}{|c|c|c|c|c|c|c|c|c|}
\hline \multirow[t]{3}{*}{ No } & \multirow{3}{*}{$\begin{array}{l}\text { Name } \\
\text { of } \\
\text { students }\end{array}$} & \multicolumn{3}{|l|}{ Score } & \multicolumn{3}{|c|}{ Percentage } & \multirow[t]{3}{*}{ information } \\
\hline & & Activites & Activites & Activites & Activites & Activites & Activites & \\
\hline & & Before & I & II & before & I & II & \\
\hline 1 & Keysa & 30 & 50 & 85 & $30 \%$ & $50 \%$ & $85 \%$ & Increased \\
\hline 2 & Aqsa & 33 & 55 & 83 & $33 \%$ & $55 \%$ & $83 \%$ & Increased \\
\hline 3 & Heltipa & 30 & 45 & 83 & $30 \%$ & $45 \%$ & $83 \%$ & Increased \\
\hline 4 & Raihan & 32 & 50 & 88 & $32 \%$ & $50 \%$ & $88 \%$ & Increased \\
\hline 5 & Qindira & 33 & 55 & 82 & $33 \%$ & $55 \%$ & $82 \%$ & Increased \\
\hline 6 & Bintang & 30 & 55 & 88 & $30 \%$ & $55 \%$ & $88 \%$ & Increased \\
\hline 7 & Juniasa & 35 & 40 & 82 & $35 \%$ & $40 \%$ & $82 \%$ & Increased \\
\hline 8 & Jenii & 30 & 45 & 90 & $30 \%$ & $45 \%$ & $90 \%$ & Increased \\
\hline 9 & Vanesa & 32 & 49 & 82 & $32 \%$ & $49 \%$ & $82 \%$ & Increased \\
\hline 10 & Hafizh & 30 & 50 & 88 & $30 \%$ & $50 \%$ & $88 \%$ & Increased \\
\hline 11 & Najwa & 30 & 45 & 81 & $30 \%$ & $45 \%$ & $81 \%$ & Increased \\
\hline
\end{tabular}




\begin{tabular}{|c|c|c|c|c|c|c|c|c|}
\hline \multirow[t]{3}{*}{ No } & \multirow{3}{*}{$\begin{array}{l}\text { Name } \\
\text { of } \\
\text { students }\end{array}$} & \multicolumn{3}{|l|}{ Score } & \multicolumn{3}{|c|}{ Percentage } & \multirow[t]{3}{*}{ information } \\
\hline & & Activites & Activites & Activites & Activites & Activites & Activites & \\
\hline & & Before & I & II & before & I & II & \\
\hline 12 & Gilang & 30 & 48 & 82 & $30 \%$ & $48 \%$ & $82 \%$ & Increased \\
\hline 13 & Azram & 30 & 50 & 86 & $30 \%$ & $50 \%$ & $86 \%$ & Increased \\
\hline 14 & Regena & 30 & 55 & 83 & $30 \%$ & $55 \%$ & $83 \%$ & Increased \\
\hline \multicolumn{2}{|c|}{ Amount } & 435 & 692 & 1183 & $435 \%$ & $692.00 \%$ & $680 \%$ & \\
\hline \multicolumn{2}{|c|}{ Average } & 31.07143 & 49.42857 & 84.5 & $31 \%$ & $49 \%$ & $85 \%$ & \\
\hline
\end{tabular}

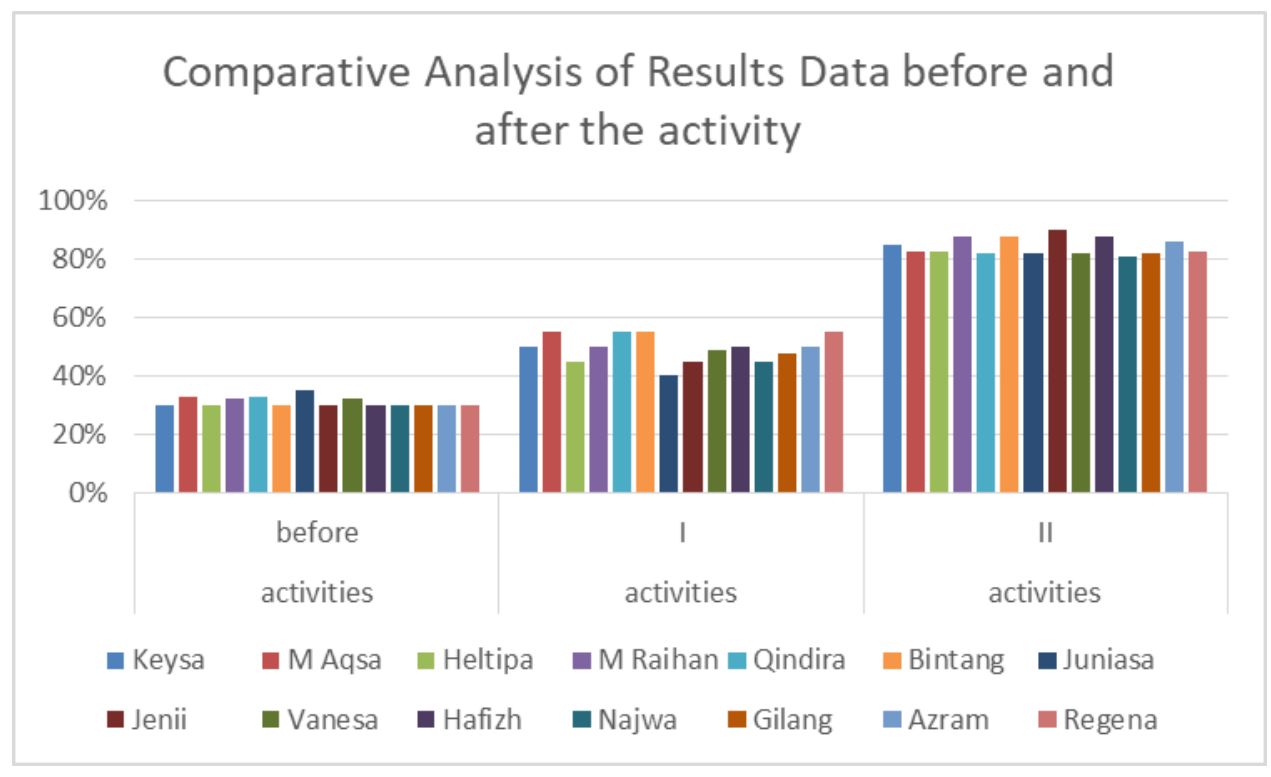

Based on the graphic above, it can be seen that increasing children's creativity and imagination through STEAM-based learning with Loose Parts media is very good. The average score before the activity was $31 \%$, Activity I was $49 \%$ and Activity II increased to $85 \%$. This shows that the creativity and imagination of children have increased significantly

After making observations and entered into this descriptive method. Then the researcher analyzed the qualitative data by interviewing the object observed with questions and producing satisfactory answers from the results of his observations.

Based on the results of learning research on Science, Technological, Engineering, Art and Mathematic with Loose Parts media carried out when the child was playing educational game tools with loose parts materials, showing that children's creativity and imagination increased.

\section{B. Discussion}


Based on the results of the discussion that the use of instructional media is very influential on the quality of learning in schools. The learning chosen by the researcher is Science, Technological, Engineering, Art and Mathematic learning with loose parts media for early childhood, an early childhood educator must be creative and always innovate to use the learning media that will be given to their students.

According to researchers, Learning Science, Technological, Engineering, Art and Mathematic with loose parts media is a suitable learning to be applied in early childhood education units. (Nurjanah 2020). Educators must adjust the condition of the child with the media that is prepared. Loose parts are provided with various choices such as language elements, art elements and mathematical elements. every child has different abilities. High artistic and language skills of children will develop even if they only use simple materials, such as using loose parts in their neighborhood.

Learning is carried out in the form of playing chili learning activities which are recognized by the Science, Technological, Engineering, Art and Mathematic learning approach which aims to encourage children's knowledge through observing, questioning and investigating. Learning in early childhood education will be interesting and fun for children and educators if the learning media is designed attractively. by learning Science, Technologic, Engineering, Art and Mathematic with loose parts media, it is able to increase the creativity and imagination of early childhood.

In the field of Science, children are taught to be able to use the scientific method approach in solving problems in everyday life. In the field of Technology, children will collaborate in terms of using technology to both process data and convey the information they get. In Engineering, children will put their findings together to create a product or they can find the right solutions. Meanwhile, in the field of Arts (Arts), children can create products / findings so that they can be accepted by the community or how they can promote these findings. Furthermore, in the field of Mathematics (Mathematics), children will use a mathematical approach in processing the data they get (Nurhikmayati 2019).

The results of this study are in line with research conducted by Novita Eka Nurjanah in 2020 by revealing the results, learning Science, Technological, Engineering, Art and Mathematic based on loose parts can increase children's creativity. 


\section{CONCLUSIONS AND SUGGESTIONS}

Based on the results of this study, creativity in children can develop well if facilitated by appropriate learning methods. STEAM learning with loose parts media is learning that gives children the freedom to create and imagine in one activity of Science, Technology, Engineering, Art and Match. This learning combines children's activities in the frame of independence to create and imagine through loose parts media in the form of materials from nature and the environment that are combined which makes children more creative and imaginative.

The results showed that the children's creativity and imagination developed significantly through learning STEAM media loose parts. This can be seen in the results of the Pre-cycle percentage of $31 \%$, then carried out in Cycle I, the percentage increase to $49 \%$ and continued in Cycle II, the increase in creativity and imagination of children is $85 \%$, which means that the creativity and imagination of PAUD Rembulan children increases through STEAM learning with media loose parts.

\section{ACKNOWLEDGMENT}

Many thanks to you who have contributed in writing this scientific paper:

1. Mrs. Tresia Harliza, S.Pd, as the Head of the Early Childhood Education Unit of Rembulan, Air Kering village, Padang Guci Hilir sub-district, Kaur district who has helped in the implementation of my research.

2. Organization of the Association of Early Childhood Educators and Education Personnel in Kaur Regency

3. Peer of Pamong Learning Non-formal education unit, learning activity center, Kaur Regency.

\section{REFFERENCE}

Agustina, Sabaria, M Nasirun, and D Delrefi. 2018. "Meningkatkan Keterampilan Motorik Halus Anak Melalui Bermain Dengan Barang Bekas." Jurnal Ilmiah Potensia 3(1): 2433.

Anggia, Alma Rara, and Untung Nopriansyah. 2018. "Mengembangkan Kreatifitas Anak Melalui Permainan Warna Dengan Media Benang." Al-Athfaal: Jurnal Ilmiah

Pendidikan Anak Usia Dini 1(2): 16-35. http://ejournal.radenintan.ac.id/index.php/alathfaal/article/view/3789.

Anggito, Albi, and Johan Setiawan. 2018. Metodologi Penelitian Kualitatif. CV Jejak (Jejak 
Publisher).

Anita Damayanti, Sriyanti Rahmatunnisa, and Lia Rahmawati. 2020. "Peningkatan

Kreativitas Berkarya Anak Usia 5-6 Tahun Melalui Pembelajaran Jarak Jauh Berbasis

Steam Dengan Media Loose Parts." Jurnal Buah Hati 7(2): 74-90.

Anufia, Budur, and Thalha Alhamid. 2019. "Instrumen Pengumpulan Data."

Budiarti, Wiwik, Sri Susilowati, and Ilya Farida. 2018. "Upaya Pemanfaatan Sampah Plastik

Kelompok Ibu-Ibu Dasawisama Gladiol 161 Di Perumahan Magersari Permai,

Kabupaten Sidoarjo.” Jurnal Komunikasi Profesional 2(2).

Chairunnisah, Andini, Sulaiman Sulaiman, and Endah Fitrani. 2019. "Rancang Bangun Alat

Pemilah Sampah Logam Dan Non Logam Otomatis Berbasis Arduino." In Bina Darma

Conference on Engineering Science (BDCES), , 79-88.

Gull, Carla, Jessica Bogunovich, Suzanne Levenson Goldstein, and Tricia Rosengarten. 2019.

"Definitions of Loose Parts in Early Childhood Outdoor Classrooms : A Scoping

Review." The International Journal of Early Childhood Environmental Education 6(3): 37-52.

Gunadi, Andi Ahmad. 2017. "Pengaruh Lingkungan Sosial Terhadap Imajinasi Anak." Refleksi Edukatika: Jurnal Ilmiah Kependidikan 7(2).

Imamah, Zakiyatul, and Muqowim Muqowim. 2020. "Pengembangan Kreativitas Dan

Berpikir Kritis Pada Anak Usia Dini Melalui Motode Pembelajaran Berbasis STEAM and Loose Part." Yinyang: Jurnal Studi Islam Gender dan Anak 15(2): 263-78.

Maryati, Febrina Dwi. 2018. "Meningkatkan Kreativitas Anak Usia Dini Melalui Metode Proyek Di RA Cendikia Al Madani Ngambur Pesisir Barat."

Nurhikmayati, Iik. 2019. "Implementasi STEAM Dalam Pembelajaran Matematika." Didactical Mathematics 1(2): 41-50.

Nurjanah, Novita Eka. 2020. “Jurnal Audi.” jurnal ilmiah kajian ilmu anak dan media informasi PUD 1(1): 19-31.

Palupi, Ajeng Putri. 2019. "Nilai Estetika Yang Terdapat Pada Limbah Kaca Di Galeri Otak Atik Daerah Yogyakarta.” INVENSI (Jurnal Penciptaan dan Pengkajian Seni) 4(1): 4352.

Prameswari, Titania, and Anik Lestariningrum. 2020. "Strategi Pembelajaran Berbasis STEAM Dengan Bermain Loose Parts Untuk Pencapaian Keterampilan 4c Pada Anak Usia 4-5 Tahun." Efektor 7(1): 24-34.

Prameswari, Titania, and Anik Lestariningrum. 2020. "Strategi Pembelajaran Berbasis STEAM Dengan Bermain Loose Parts Untuk Pencapaian Keterampilan 4c Pada Anak Usia 4-5 Tahun." Efektor 7(1): 24-34.

Pratiwi, Dona Dinda et al. 2021. "Application of Algebraic Tile Media with Gasing: Ability to Understand Mathematical Concepts and Student Creativity." IOP Conference Series: Earth and Environmental Science 1796(1).

Puspita, Widya Ayu. 2019. "Penggunaan Loose Parts Dalam Pembelajaran Dengan Muatan STEM." Kepala BP PAUD Dan Pendidikan Masyarakat Jawa Timur Penasehat Kepala Seksi Informasi Dan Kemitraan 17.

Rijali, Ahmad. 2019. “Analisis Data Kualitatif.” Alhadharah: Jurnal Ilmu Dakwah 17(33): 81.

Rofi'ah, Siti, Anisa Setyowati, and Ribkha Itha Idhayanti. 2018. "Media Gambar Flashcard Dalam Menstimulasi Perkembangan Bahasa Anak Usia 3-4 Tahun." Jendela Inovasi Daerah 1(2): 78-92.

Sugawara, Etsuko, and Hiroshi Nikaido. 2014. "Properties of AdeABC and AdeIJK Efflux 
Systems of Acinetobacter Baumannii Compared with Those of the AcrAB-TolC System of Escherichia Coli." Antimicrobial agents and chemotherapy 58(12): 7250-57.

Ubaidillah, Khasan. 2018. "Pembelajaran Sentra BAC (Bahan Alam Cair) Untuk

Mengembangkan Kreativitas Anak; Studi Kasus RA Ar-Rasyid.” AL-ATHFAL :

JURNAL PENDIDIKAN ANAK 4(2): 161-76. http://ejournal.uinsuka.ac.id/tarbiyah/index.php/alathfal/article/view/2103.

Wahyuni, Sri, Reswita Reswita, and Mar'atul Afidah. 2020. "Pengembangan Model Pembelajaran Sains, Technology, Art, Engineering And Mathemathic Pada Kurikulum PAUD.” Jurnal Golden Age 4(02): 297-309.

Wahyuningsih, Siti et al. 2019. "Efek Metode STEAM Pada Kreatifitas Anak Usia 5-6

Tahun." Jurnal Obsesi : Jurnal Pendidikan Anak Usia Dini 4(1): 305.

Wahyuningsih, Siti, Adriani Rahma Pudyaningtyas, and Novita Eka Nurjanah. 2020. "The Utilization Of Loose Parts Media In Steam Learning For Early Childhood." 2: 1-5.

Wiyani, Novan Ardy. 2019. "Mengelola \& Mengembangkan Kecerdasan Sosial \& Emosi Anak Usia Dini."

Yayuk, Sri, and Sugiyono Sugiyono. 2019. "Pengaruh Kepemimpinan Kepala Sekolah Dan Biaya Pendidikan Terhadap Kualitas Proses Belajar Mengajar Dan Dampaknya Dengan Kompetensi Lulusan SMK Di Kabupaten Gunungkidul.” Jurnal Akuntabilitas Manajemen Pendidikan 7(1): 84-96. 